\title{
Peran Kelompok Nelayan Dalam Aktivitas Pariwisata Di Desa Kedonganan Kuta, Bali
}

Lisbet Sihombing a, 1 , Saptono Nugroho a, 2

1lialisbeth@gmail.com, 22saptono_nugroho@unud.ac.id

a Program Studi S1 Destinasi Pariwisata, Fakultas Pariwisata,Universitas Udayana, Jl. Dr. R. Goris, Denpasar, Bali 80232 Indonesia

\section{Abstract}

This research is motivated by the important roles of the Kedonganan people to gather in a fishing group community to develop of tourism activity in Kedonganan Beach. Fishermen Group in Kedonganan Beach is required to become a tourism actors with many demands of tourists that visiting to Kedonganan village of Fishermen Group. The purpose of this research to find out the forms of involvement or the roles by fishermen group in supporting the tourism activity ini Kedonganan village.

The type of data in this study usedescriptive qualitative. Data collection techniques use in this research are interviews, study documents or literature. Techniques of informan determining use dept interviews with determining the key informan. The key informant which is selected in this study is Putra Bali's Fishermen Group in Kedonganan village. The data analysis techniques are uing Data Reduction, Data Display, and Conclusion Drawing/Verification.

The research concludes that fishermen group has an important role in tourism activity in Kedongananvillage, there are in economic, social, cultural, environmental, and political. But there are problems of the role of the fishermen in the field of the environment, because it is less in keeping it clean, the plastic waste and used garbage incinerator make bad sights and the sand starts to dirty. The fishing groups should form a section in them organizational structure that works specifically to maintain the cleanliness of the beach area. They should also add some attractions, which besides being a tourist guide who wants to see the beauty beneath the sea, the fishing activity such as knitting nets can also be used as an educational tour on marine fisheries. Thus, tourists can also invited to participate in fishing activity, and diving to study marine tourism, and preservation.

\section{Keywords : Comunity Based Tourism (CBT), Fishermen Group, Role of Fishermen Group}

\section{PENDAHULUAN}

Meyers (2009) dalam Widyatmaja, dkk (2010) menyatakan bahwa Pariwisata merupakan suatu kegiatan perjalanan yang dilakukan untuk sementara waktu dari tempat tinggal semula ke daerah tujuan dengan alasan bukan untuk menetap atau mencari nafkah melainkan hanya untuk bersenang-senang, memenuhi rasa ingin tahu, menghabiskan waktu senggang atau waktu libur serta tujuantujuan lainnya.

Pariwisata saat ini berkembang dengan adanya dukungan dari masyarakat. Sebagai salah satu pilar yang dapat membangun pariwisata, masyarakat memiliki peranan penting untuk melanjutkan perkembangan pariwisata tersebut.

Masyarakat juga memiliki hak untuk mengembangkan dan memajukan daerahnya dengan potensi pariwisata yang dimilikinya, dengan perkembangan pariwisata yang begitu pesat masyarakat juga dituntut untuk aktif dalam dunia kepariwisataan.

Menurut Undang-Undang No. 10 Tahun 2009 tentang kepariwisataan menyatakan bahwa pariwisata merupakan berbagai macam kegiatan wisata dan didukung berbagai fasilitas serta layanan yang disediakan oleh masyarakat, pengusaha, pemerintah, dan pemerintah daerah.

Selain itu, kepariwisataan juga bertujuan untuk meningkatkan pertumbuhan ekonomi, meningkatkan kesejahteraan rakyat, menghapus kemiskinan, mengatasi pengangguran, melestarikan alam, lingkungan, dan sumber daya, memajukan kebudayaan, mengangkat citra bangsa, memupuk rasa cinta tanah air, memperkukuh jati diri dan kesatuan bangsa dan mempererat persahabatan antar bangsa.

Penelitian ini dilakukan di Desa Kedonganan yang terletak di Selatan Pulau Bali. Desa Kedonganan memiliki ciri khas tersendiri sehingga dikenal oleh wisatawan baik itu wisatawan nusantara maupun mancanegara. Desa Kedonganan yang terletak di Kabupaten Badung, tepatnya di Kecamatan Kuta.

Desa Kedonganan merupakan salah satu daya tarik wisata kuliner yang ada di Bali bagian selatan. Melalui proses pemberdayaan masyarakat lokal, diharapkan agar masyarakat juga dapat semakin mandiri dan memiliki kemampuan untuk mengimplementasikan keputusan-keputusan serta memberdayakan 
sumber daya lokal dalam meningkatkan kesejahteraannya.

Masyarakat Desa Kedonganan dari dulunya sebagian besar pekerjaannya adalah nelayan, dan sebagiannya lagi merupakan petani dan pedagang. Desa tersebut dikenal oleh wisatawan karena hasil lautnya, yaitu ikan laut sehingga pantai tersebut kerap disebut dengan kampung nelayan. Ikan laut juga merupakan salah satu sumber daya alam yang dimiliki Desa Kedonganan dapat dimanfaatkan oleh masyarakat nelayan untuk kesejahteraan hidupnya, dengan mengaplikasikannya kedalam kegiatan kepariwisataan di Desa tersebut.

Sumber daya alam yang dimiliki desa tersebut juga dapat menjadi daya tarik tersendiri bagi wisatawan untuk berkunjung. Seperti saat ini di desa tersebut diadakan beberapa atraksi wisata kuliner, yang menjual hasil lautnya di Pasar Ikan Desa Kedonganan. Sore hari hingga malam hari para pemilik cafecafe dan restoran di pinggir pantai mengadakan pameran hasil lautnya dengan membuat menu makanan dari hasil laut Kedonganan itu sendiri.

Oleh karena itu, peran masyarakat Desa Kedonganan yang berhimpun dalam kelompok nelayan memiliki peranan penting dalam perkembangan dan aktivitas pariwisata di Pantai Kedonganan. Masyarakat nelayan di Pantai Kedonganan ini dituntut untuk menjadi pelaku wisata dengan banyaknya permintaan wisatawan yang berkunjung ke Desa Kedonganan akan wisata kulinernya.

Berdasarkan fenomena-fenomena diatas, maka maksud penelitian ini dianggap penting dilakukan dengan tujuan untuk mengetahui apa peran kelompok nelayan dalam aktivitas kepariwisataan di Desa Kedonganan.

\section{TINJAUAN PUSTAKA}

Adapun beberapa laporan penelitian sebelumnya yang memiliki keterkaitan sebagai bahan tinjauan pustaka dalam penelitian ini, yang ditinjau berdasarkan fokus dan lokus penelitian, antara lain sebagai berikut:

Hasil penelitian sebelumnya yang pertama dilakukan oleh Sipahelut (2010) tentang analisis pemberdayaan kelompok nelayan di Kecamatan Tobelo Kabupaten Halmahera Utara. Persamaan fokus penelitian yang menjadi suatu acuan dalam penelitian ini, yaitu tentang pemberdayaan kelompok nelayan dalam aktivitas kepariwisataannya. Dimana kedua lokus kaya akan sumberdaya perikanan dan kelautannya. Sebagian besar sumber kehidupan kelompoknya bersumber dari hasil lautnya, dan bekerja sebagai nelayan. Pada mulanya kedua lokus tersebut juga sama-sama tergolong pada kelompok yang masih hidup dibawah garis kemiskinan. Maka untuk mengentaskan kemiskinan tersebut masyarakat lokal mereka berinisiatif sendiri untuk ikut aktif dan melakukan peranan penting dalam pengembangan pariwisatanya. Perbedaan antara kedua penelitian tersebut adalah lokus, dimana lokasi penelitian sebelumnya dilakukan di Kecamatan Tobelo Kabupaten Halmahera Utara, sementara penelitian ini dilakukan Desa Kedonganan, Kuta, Bali.

Penelitian sebelumnya yang kedua dilakukan oleh Suasapha (2016) tentang implementasi konsep pariwisata berbasis kelompok dalam pengelolaan Pantai Kedonganan. Penelitian ini memiliki lokus yang sama yaitu terletak di Desa Kedonganan, Kecamatan Kuta Tengah, Kabupaten Badung, Bali. Desa Kedonganan telah menerapkan konsep pariwisata berbasis masyarakat, namun yang membuat kedua penelitian ini berbeda yaitu fokus penelitian, dimana penelitian yang akan dilakukan lebih difokuskan terhadap kelompok nelayannya, untuk mengetahui bagaimana peranannya dalam aktivitas kepariwisataan di Desa Kedonganan.

Landasan konsep yang digunakan dalam penelitian ini yaitu: konsep kepariwisataan yang digunakan untuk mengkaji tentang kepariwisataan di Desa Kedonganan. Konsep peran untuk mengetahui peran kelompok nelayan di Desa Kedonganan sebagai pemeran utama (actor) dalam aktivitas kepariwisataan di Desa Kedonganan. Konsep pariwisata berbasis masyarakat (CBT) untuk mengkaji pembangunan pariwisata di Desa Kedonganan yang ditinjau dari 5 aspek, antara lain aspek ekonomi, aspek budaya, aspek lingkungan, aspek politik, dan aspek sosial Suansri (2003). Konsep nelayan merupakan kelompok masyarakat pesisir setelah pembudidaya ikan dan pedagang yang secara langsung mengusahakan dan memanfaatkan sumber daya ikan melalui kegiatan penangkapan dan budidaya, yang ikut serta sebagai aktor dalam pengembangan pariwisata di Desa Kedonganan, dan konsep sumber daya alam untuk mengkaji sumber daya alam yang dimiliki, khususnya 
tentang budidaya dan pemanfaatan ikan yang menjadi sumber penghasilan bagi masyarakat nelayan di Desa Kedonganan.

\section{METODE}

Jenis dan sumber data yang digunakan dalam penelitian ini adalah jenis data kualitatif (Taylor, dkk, 1990) yaitu data-data berupa kondisi masyarakat nelayan, dan peran masyarakat nelayan dalam aktivitas kepariwisataan di Desa Kedonganan, kemudian data kuantitatif (Kusmayadi dan Sugiarto, 2000) yaitu data-data berupa jumlah anggota kelompok nelayan Putra Bali.

Dalam penelitian ini sumber data yang digunakan adalah data primer dan sekunder (Moleong, 2012). Data primer yaitu hasil wawancara dengan narasumber mengenai peran masyarakat nelayan dalam aktivitas pariwisata di Desa Kedonganan, sedangakan data sekunder yaitu data-data dari hasil penelitian sebelumnya, sumber buku mengenai konsep yang digunakan dan berkaitan dalam penelitian ini, antara lain konsep kepariwisataan, konsep peran, konsep pariwisata berbasis masyarakat (CBT) oleh Suansri (2003), konsep nelayan, dan konsep sumber daya alam.

Teknik pengumpulan data dilakukan dengan observasi, wawancara, dan dokumentasi (studi kepustakaan). Selanjutnya teknik penentuan informan yang digunakan adalah teknik purposive sampling (sampel bertujuan) yaitu eknik pengumpulan data dengan penentuan nominasi subjek penelitian oleh peneliti berdasarkan pada kelayakan pengetahuan mereka terhadap objek penelitian, serta menunjuk atau menemukan orang tertentu sebagai subjek dan informan penelitian dan peneliti mengetahui orang tersebut memiliki pengetahuan yang luas terhadap objek penelitian (Burhan Bungin, 2011).

Informan yang dipilih yaitu ketua Kelompok Nelayan Putra Bali (Made Gita Adnyana), dan beberapa masyarakat nelayan di Desa Kedonganan, antara lain Agus, dan Suarjana. Teknik analisis data menggunakan teknik analisis data kualitatif oleh Miles dan Huberman, yang meliputi reduksi data, penyajian data, dan penarikan kesimpulan dan verifikasi (Sugiyono, 2014).

\section{IV.HASIL DAN PEMBAHASAN 4.1 Peran Kelompok Nelayan}

Kelompok Nelayan Putra Bali adalah suatu himpunan masyarakat nelayan, yang merupakan bagian dari masyarakat lokal dari Desa Kedonganan itu sendiri. Mereka ini memegang aspek aktif dalam hal menangkap dan membudidayakan ikan laut Desa Kedonganan dan tidak lepas dari peranannya dalam pengembangan pariwisata di desa tersebut.

Menurut Suansri (2003), ada lima aspek yang menjadi acuan dalam pengembangan pariwisata berbasis masyarakat, khususnya nelayan yang merupakan masyarakat lokal Desa Kedonganan, antara lain aspek ekonomi, aspek sosial, aspek budaya, aspek lingkungan, dan aspek politik.

\subsubsection{Aspek Ekonomi}

Keberadaan kelompok nelayan ini jelas sangat berperan baik dalam pengembangan pariwisata di Desa Kedonganan, dimana hingga saat ini semakin bertambah keanggotaan dari kelompok nelayan tersebut, sehingga dengan itu semakin banyak pula yang menyadari akan pentingnya pemanfaatan dan pelestarian sumber daya alam yang dimiliki Desa Kedonganan, khususnya dalam pembudidayaan hasil laut, seperti ikan, kerang, dan lain-lain. Hal tersebut akan menunjang perekonomian masyarakat nelayan dan perekonomian daerah Desa Kedonganan, baik dibidang perikanan dan juga kepariwisataan.

Selain menangkap dan membudidaya ikan, kelompok nelayan dapat juga melakukan aktivitas lain seperti aktivitas di sektor pariwisata, yang juga dapat menghasilkan uang dengan memanfaatkan hasil laut dan biota alam bawah laut, yaitu dengan memanfaatkan ikan laut sebagai produk utama wisata kuliner di Desa Kedonganan. Selain berwisata kuliner disana, ada juga beberapa wisatawan yang ingin berwisata untuk menikmati aktivitas nelayan baik di pantai dengan melihat-lihat sambil belajar bagaimana cara nelayan merajut jala, maupun di dalam bawah laut (menyelam) untuk melihat keindahan bawah laut. Hal ini akan menjadi pemasukan tambahan bagi para nelayan. 


\subsubsection{Aspek Sosial}

Kelompok nelayan Putra Bali merupakan suatu kelompok yang terorganisir. Terorganisir maksudnya adalah kelompok nelayan Putra Bali sebagai suatu kumpulan yang nyata, teratur dan masing-masing individu melaksanakan peranperannya dengan saling berkaitan untuk mencapai tujuan bersama.

Dalam kelompok nelayan Putra Bali ini terdapat ketua dan anggota sesuai dengan struktur organisasinya. Masing-masing individu memiliki peran untuk tujuan bersama, yaitu menangkap dan membudidayakan hasil laut untuk dijual kepada masyarakat maupun wiatawan yang berkunjung ke Desa Kedonganan.

Seluruh anggota dan nelayan dalam kelompok nelayan Putra Bali diberikan upah/gaji, jaminan kesehatan oleh ketua kelompok dengan mendaftarkan kartu BPJS, dan pertanggungjawaban atas keselamatan kerja.

Selain itu adanya peningkatan kualitas hidup, pembagian peran yang adil antara lakilaki dan perempuan, generasi muda dan tua dalam keorganisasian, bahwa yang menjadi nelayan atau melaut dalam kelompok ini adalah hanya laki-laki saja, sementara perempuan bisa ditempatkan dalam kepengurusan kelompok nelayan Putra Bali yang disesuaikan dengan pendidikannya.

Dalam organisasi kelompok nelayan Putra Bali terdapat mekanisme penguatan organisasi komunitas, dengan adanya struktur organisasi, maka jelas pula tugas dan tanggung jawab dari setiap departemen/seksi dalam kepengurusan organisasi tersebut.

Untuk meningkatkan kualitas hidupnya kelompok nelayan harus bekerja setiap harinya berlayar di laut mulai dari 16.00 Wita hingga 09.00 Wita esoknya. Usai itu mereka bekerja di darat dengan merajut jala serta mengeluarkan ikan hasil tangkapannya dari jukung atau kapalnya untuk siap di distribusikan ke pasar ataupun ke kafe-kafe, maupun ke beberapa restoran.

Anggota Kelompok Nelayan Putra Bali tidak hanya masyarakat yang berasal dari Bali saja, tetapi ada yang berasal dari luar Bali, dan mereka tidak memiliki pekerjaan lain selain menjadi nelayan dalam kelompok tersebut. Tetapi ada beberapa anggota kelompok yang jabatannya lebih tinggi, dan memiliki profesi lain seperti menjadi karyawan di beberapa cafe atau restoran di desa tersebut. Mereka itu adalah orang-orang yang sudah lama menjadi anggota kelompok dan merupakan penduduk lokal Bali yang memiliki pendidikan yang lebih tinggi dari anggota lainnya.

Selain menjadi pembudidaya ikan, nelayan juga berpeluang mendapatkan lapangan pekerjaan di sektor pariwisata, dimana Ketut Suarjana mengatakan bahwa:

"Selain melaut, nelayan juga berperan aktif di sektor pariwisata, dimana nelayan dapat menjadi guide bagi wisatawan yang ingin melihat biota alam bawah laut, serta wisatawan yang ingin ikut menikmati kehidupan nelayan saat menangkap ikan di tengah laut, hal ini akan menambah pendapatan nelayan dibidang jasa/guide, sehingga pendapatan ekonomi tidak hanya didapat dari hasil ikan saja, namun dengan melakukan pekerjaan tambahan yang juga dianggap tidak mengganggu aktivitasnya sebagai penangkap ikan, sementara pihak kelompok yang kerap disebut-sebut "bos" oleh para nelayan juga tidak merasa keberatan akan hal itu". (wawancara dengan Ketut Suarjana, 05 Juni 2016).

\subsubsection{Aspek Budaya}

Kelompok Nelayan Putra Bali juga dituntut untuk wajib menghormati kebudayaan lokal, yaitu budaya Bali tentunya. Berhubung anggota kelompok nelayan Putra Bali tidak semuanya yang merupakan masyarakat lokal dan bukan hanya orang Bali saja, namun ada juga nelayan yang berasal dari luar Bali, misalnya orang Jawa, maka didalam komunitas tentunya harus saling menghormati budaya yang berbeda, mendorong berkembangnya pertukaran budaya.

Dalam setiap upacara adat ataupun agama, umat lain harus siap untuk saling menghormati dan mendukung satu sama lain. Ketut Suarjana, sekaligus mewakili ketua Kelompok Nelayan Putra Bali juga mengatakan bahwa:

"Setiap ada upacara adat maupun keagamaan di desa, kelompok ikut 
berkontribusi dalam upacara tersebut, seperti misalnya setiap 3 (tiga) tahun sekali ada upacara ngaben massal, dan pembuangan abu mayat ke laut (nganyut), jadi acara tersebut ditugasi oleh kedua kelompok nelayan yang ada di Desa Kedonganan, antara kelompok nelayan Putra Bali dan kelompok nelayan Kerta Bali secara bergiliran, dimana jadwal untuk mendapat giliran telah diatur oleh desa adat, selain itu ada kontribusi berupa dana punia yang diberikan kepada Desa Pakraman Kedonganan". (wawancara dengan Ketut Suarjana, 06 Juni 2016).

Kelompok Nelayan Putra Bali, mayoritas anggotanya beragama Hindu menjalankan upacara keagamaan sesuai dengan tanggal di kalender, selain itu ada beberapa program tertentu, seperti "Upacara Ngaben Massal", serta pembuangan abu mayat ke laut selalu diadakan setiap tiga tahun sekali, upacara tersebut ditugasi oleh kedua kelompok nelayan yang ada di Desa Kedonganan secara bergiliran. Kelompok Nelayan Putra Bali juga ikut berkontribusi dengan memberikan berupa "dana punia" kepada Desa Pakraman Kedonganan.

Kemudian pada saat hari raya besar agama lain (nonHindu), atau misalnya Islam, dimana didalam kelompok terdapat ada banyak nelayan yang beragama Islam juga disana, kelompok juga ikut menghargai adanya perbedaan keyakinan, misalnya pada saat Hari Raya Idul Fitri, kelompok memberikan kesempatan cuti kepada setiap nelayan yang beragama Muslim untuk dapat pulang ke kampung halamannya, dan bertemu dengan sanak-keluarganya.

\subsubsection{Aspek Lingkungan}

Kelompok Nelayan Putra Bali harus mempelajari carryng capacity area, dimana kelompok nelayan Putra Bali yang berlokasi di sebelah selatan pantai Kedonganan wajib untuk menjaga kebersihan kawasan aktivitas melautnya, baik di pantai maupun di laut, dan mengatur pembuangan sampah. Hal tersebut bertujuan untuk meningkatkan rasa peduli akan perlunya konservasi, khususnya pada konservasi sumber daya alam bawah laut, seperti ikan-ikannya.

Setiap dua bulan sekali, kedua kelompok nelayan yang ada di Kedonganan tersebut melakukan program bakti sosial, yaitu kebersihan kawasan pantai secara massal, jadi pada saat itulah kedua kelompok nelayan saling bekerjasama dalam melakukan kebersihan kawasan pantai. Itu merupakan salah satu bentuk kepedulian mereka terhadap kawasan sumber mata pencaharian mereka.

Selain keterlibatan nelayan dalam menjaga kebersihan pantai, ada petugas khusus juga dari desa pakraman yang bertugas untuk membersihkan pantai, namun pembersihan yang dilakukan oleh petugas tersebut hanyalah di sekitaran tepi-tepi laut, biasanya tidak sampai kepada wilayah dimana tempat parkiran kapal-kapal nelayan. Kemudian untuk dibeberapa area, masih terdapat tempat bakarbakar sampah plastik ditepi pantai. Salah satu nelayan dari Kelompok Nelayan Putra Bali mengatakan:

"untuk kegiatan bakar-bakar sampah itu sendiri, kami nelayan yang melakukannya sendiri, karena akan tidak ada lahan yang disediakan untuk pembuangan sampah plastik di kawasan pantai, jadinya kami kumpulkan saja disuatu titik di pantai ini, lalu kami bakar, agar pantai ini bersih dari serakan sampah plastik", katanya dengan logat Jawanya. (wawancara dengan Agus, 06 Juni 2016).

Bakar-bakar sampah ini dilakukan oleh nelayan itu sendiri, dengan alasan bahwa tidak ada lahan yang disediakan untuk pembuangan sampak plastik di kawasan pantai, jadi itu merupakan upaya nelayan agar pantai terlihat bersih saja dari serakan sampah plastik.

\subsubsection{Aspek Politik}

Pariwisata Desa Kedonganan dikelola oleh Desa Adat Kedonganan dan dijalankan dengan berbasis masyarakat lokal. Segala kebijakan dan kegiatan pengelolaan dibuat berdasarkan hasil musyawarah desa, dan membuat suatu kebijakan lokal berupa awigawig yang merupakan aturan yang dibuat oleh 
krama desa sebagai pedoman dalam pelaksanaan Tri Hita Karana.

Dalam hal ini juga mengatur, menentukan dan meningkatkan partisipasi dari penduduk lokal, peningkatan kekuasaan komunitas yang lebih luas, serta menjamin hak-hak dalam pengelolaan SDA di Kawasan Pantai Kedonganan.

\subsection{Simpulan}

V. SIMPULAN DAN SARAN

Berdasarkan pada pembahasan dan hasil penelitian dapat disimpulkan bahwa pariwisata Desa Kedonganan memiliki perkembangan yang cukup baik. Hal tersebut dilihat dari manfaat ekonomi pariwisata yang dirasakan secara langsung oleh masyarakat lokal di Desa Kedonganan, yang didominasi oleh masyarakat nelayan, dengan memanfaatkan kekayaan lautnya, yaitu ikan lautnya, masyarakat lokal mampu menghidupi kehidupan sehari-harinya dan keluarga. Masyarakat lokal nelayan yang berhimpun dalam suatu kelompok nelayan juga memiliki peranan penting dalam pengembangan pariwisata di daerahnya.

Adapun peran kelompok nelayan dalam kepariwisataan di Desa Kedonganan dapat dibagi menjadi lima aspek, antara lain: Pertama adalah aspek ekonomi, dimana kelompok nelayan mampu untuk ikut berkontribusi dalam meningkatkan perekonomian daerah, baik dibidang perikanan dan juga kepariwisataannya. Kedua adalah aspek sosial, kelompok nelayan berperan sebagai penyedia lapangan pekerjaan bagi masyarakat lokal. Ketiga yaitu aspek budaya, dimana didalam Kelompok Nelayan Putra Bali sangat menghormati budaya lokal, tentunya budaya Bali dan Hindu. Kelompok nelayan tersebut selalu menjalankan upacara keagamaan seperti Upacara Ngaben Massal, dandalam setiap upacara adat ataupun agama, umat lain harus siap untuk saling menghormati dan mendukung satu sama lain. Hal ini mendorong berkembangnya pertukaran budaya dan adanya budaya pembangunan yang melekat erat dalam budaya lokal. Keempat adalah aspek lingkungan, dimana dalam aspek ini kelompok nelayan Putra Bali juga melibatkan anggota kelompok dan nelayan dalam kebersihan lingkungan, baik didalam laut maupun pantainya.
Kelima adalah aspek politik, dimana pariwisata Desa Kedonganan dikelola oleh Desa Adat Kedonganan dan dijalankan dengan berbasis masyarakat lokal, maka segala kebijakan dan kegiatan pengelolaan dibuat berdasarkan hasil musyawarah desa, dan membuat suatu kebijakan lokal berupa awigawig yang merupakan aturan yang dibuat oleh krama desa sebagai pedoman dalam pelaksanaan Tri Hita Karana. Kelompok nelayan juga ikut serta dalam musyawarah dan pengambilan keputusan bersama dalam pengelolaan pariwisata di Dalam hal ini juga mengatur, menentukan dan meningkatkan partisipasi dari penduduk lokal, peningkatan kekuasaan komunitas yang lebih luas, serta menjamin hak-hak dalam pengelolaan SDA di Kawasan Pantai Kedonganan.

\subsection{Saran}

Berdasarkan hasil observasi, saat ini peran serta masyarakat nelayan Desa Kedonganan dapat disimpulkan masih belum terlaksana secara optimal, salah satunya peran terhadap menjaga kebersihan lingkungan masih belum maksimal. Kesadaran nelayan akan kebersihan pantai dan keamanan serta kenyamanan wisatawan kurang diperhatikan, karena masih ada nelayan yang membuang sampah plastik, tulang ikan yang berjatuhan di pantai dari kapal/jukung nelayan masih banyak berjatuhan di kawasan pantai. Serta tidak sedikit nelayan yang melakukan bakar-bakar sampah di pantai, potongan kayu besar serta ranting-ranting pohon berserakan di pantai. Hal ini jelas merusak lingkungan, khususnya pada pasirnya, serta menciptakan pemandangan yang kurang sedap karena sampah-sampah yang berserakan tersebut.

Untuk mengoptimalkan peran aktif kelompok nelayan dalam aktivitas kepariwisataan. Ada beberapa hal yang dapat dijadikan sebagai bahan acuan atau saran saya kepada pihak kelompok nelayan, antara lain:

1. Agar menyusun anggota keorganisasian yang khusus bertugas untuk kebersihan kawasan pantai, sehingga tulang-tulang ikan ataupun ikan-ikan yang jatuh/meloncat dari jukung saat bersandar, agar langsung dapat dibersihkan oleh petugas khusus kebersihan tersebut

2. Menambahkan atraksi wisata, dimana selain menjadi guide wisatawan yang ingin melihatkeindahan bawah laut, aktivitas nelayan seperti merajut jala juga dapat 
dijadikan sebagai wisata edukasi tentang perikanan dan kelautan. Dengan itu, wisatawan juga diajak untuk mengikuti aktivitas nelayan, dan menyelam untuk mempelajari wisata bahari, dan pelestariannya

3. Melibatkan istri para nelayan untuk ikut berperan dalam kegiatan pariwisata di sekitar pantai, misalnya dengan berjualan makanan tradisional, ataupun dengan menjual berbagai aksesoris khas Bali di pantai.

\section{DAFTAR PUSTAKA}

Arikunto, S. 2002. Prosedur Penelitian: Suatu Pendekatan Praktek. Jakarta: Rineka Cipta.

Bungin, Burhan. 2012. Metode Penelitian Kualitatif: Aktualisasi Metodologis ke Arah Ragam Varian Kontemporer. Jakarta: Rajawali Pers.

Gunawan, Imam. 2013. Metodologi Penelitian Kualitatif: Teori dan Praktik. Jakarta: PT. Bumi Aksara.

Kusmayadi dan Endar Sugiarto.2000. Metodologi Penelitian dalam Bidang Kepariwisataan.Jakarta: PT. Gramedia Pustaka.

Moleong, Lexy J. 2009. Metode Penelitian Kualitatif. Bandung: PT. Remaja Rosdakarya.

Suansri, Potjana. 2003. Community Based TourismHandbook. Bangkok: Responsible Ecological Social Tour(REST) Project.

Sugiyono. 2014. Metode Penelitian Kuantitatif, Kualitatif dan RdanD. Bandung : Penerbit Alfabeta.

Suwena, I Ketut dan I Gst Ngr Widyatmaja. 2010. Pengetahuan Dasar Ilmu Pariwisata. Kampus Unud Sudirman Gedung Pascasarjana: Udayana University Press.

Tuwo, Ambo. 2011. Pengelolaan Ekowisata Pesisir dan Laut: Pendekatan Ekologi, Sosial-Ekonomi, Kelembagaan, dan Sarana Wilayah. Surabaya: Brilian Internasional.

Wardiyanta. 2006. Metode Penelitian Pariwisata. Yogyakarta: Penerbit Andi.

Sumber lainnya/Web:

Jaya, Indra. 2015. Partisipasi Kelompok Nelayan Pesisir Karya Segara dalam Konservasi Terumbu Karang di Pantai Serangan Denpasar, diakses dalam https://wisuda.unud.ac.id/pdf/0301605011-1PENDAHULUAN.pdf/diunduh dan disalin pada tanggal 22 Maret 2016

Labda Pacingkreman Desa Pakraman Kedonganan, diakses dalam http://www.lpdKedonganan.com diunduh dan disalin pada tanggal 06 Juni 2016

Sipahelut, Michel. 2010. Analisis Pemberdayaan Kelompok Nelayan di Kecamatan Tobelo Kabupaten Halmahera Utara, diakses dalam http://mfile.narotama.ac.id/files/Umum/JURNAL \%20IPB/ANALISIS\%20PEMBERDAYAAN\%20KEL OMPOK\%20NELAYAN\%20DI\%20KECAMATAN\%2 OTOBELO\%20KABUPATEN\%20HALMAHERA\%20 UTARA.pdf diunduh dan disalin pada tanggal 23 Maret 2016

Suasapha, Anom Hery. 2016. Implementasi Konsep Pariwisata Berbasis Kelompok dalam Pengelolaan Pantai Kedonganan, diakses dalam http://ojs.unud.ac.id/index.php/jumpa/article/vie $\underline{w} / 18346 / 11870$, diunduh dan disalin pada tanggal 23 Maret 2016 